\title{
Production, Purification, and Characterization of Alkaline Protease from Aspergillus flavus and its Compatibility with Commercial Detergents
}

\author{
Amtul W. Wajeeha, ${ }^{a}$ M. Javaid Asad, ${ }^{\mathrm{a}}$ Raja Tahir Mahmood, ${ }^{\mathrm{b}}$ Tayyaba Zainab, ${ }^{\mathrm{a}}$ Sidrah Nazir, ${ }^{\mathrm{a}}$ \\ Jehangir Khan, ${ }^{\mathrm{c}}$ Muhammad B. Shah, ${ }^{\mathrm{d}}$ Maqsood Ahmed, ${ }^{\mathrm{b}}$ Syed L. Shah, ${ }^{\mathrm{e}}$ Muhammad Ismail, ${ }^{\mathrm{e}}$ \\ Nasib Zaman, ${ }^{\mathrm{f}}$ Dawood Ahmed, ${ }^{\mathrm{g}}$ M. Imran Khan, ${ }^{\mathrm{h}}$ and Muhammad Rizwan ${ }^{\mathrm{f}}$
}

\begin{abstract}
Aspergillus flavus was used to produce alkaline protease. Solid state fermentation (SSF) strategy was adopted to explore the most favorable physical and nutritional conditions for enzyme production. Maximum production was achieved at $\mathrm{pH} 6.0$ and a temperature of $30^{\circ} \mathrm{C}$ after $84 \mathrm{~h}$ of growth period. For the optimization of the chemical parameters, different carbon and nitrogen sources were used including glucose, fructose, sucrose, ammonium sulphate, and urea. Maximum production was observed with $0.3 \%$ concentration of all the compounds. Ammonium sulphate salting out and gel chromatography was used to purify the enzyme. The enzyme was completely precipitated out at $80 \%$ saturation. The value of $V_{\max }$ was $3.9 \mathrm{U} / \mathrm{mL}$, while the value of $K_{\mathrm{m}}$ was $1.9 \mathrm{mg} / \mathrm{mL}$. The enzyme was tested for its compatibility with a few famous detergents available on the market. With the alkaline protease under study, the enzyme displayed a maximum retention of its activity i.e. $80.8 \%$ in the presence of commercial detergent Surf excel. The activity dropped down to $61.5 \%$ when the enzyme was allowed to work in the presence of another locally used detergent, i.e., Bonus. Protease production from A. flavus was carried out on rice bran and wheat bran and the wheat bran gave better results.
\end{abstract}

Keywords: Alkaline protease; Aspergillus flavus; Ammonium sulfate; Gel chromatography; Detergent compatibility

Contact information: a: Department of Biochemistry, Pir Mehr Ali Shah, Arid Agriculture University, Rawalpindi, Pakistan; b: Department of Biotechnology, Mirpur University of Science and Technology, Mirpur10250 AJK, Pakistan; c: Department of Biosciences, University of WAH, WAH Pakistan, d: Department of Plant Breeding \& Genetics, Balochistan Agriculture College Quetta, Pakistan; e: Pakistan Museum of Natural History, Garden Avenue Shakarparian Islamabad (Pakistan), f: Center for Biotechnology and Microbiology, University of Swat, KPK, Pakistan, g: Department of Medical Laboratory Technology, The University of, Haripur, KPK, Pakistan, h: Department of Mathematics \& Statistics, University of Agriculture Faisalabad;

*Corresponding author: javaidasad@uaar.edu.pk

\section{INTRODUCTION}

Enzymes are the catalysts that regulate many chemical reactions occurring in the living body and are called biocatalysts (Raimi et al. 2011). Proteases are enzymes that promote the cleavage of peptide bonds through hydrolysis (Franco et al. 2017). They can be acidic, neutral, or alkaline. Alkaline proteases show the maximum rate of reaction at high $\mathrm{pH}$ values. They can withstand high temperature as well. Therefore, they have become of crucial importance to many industries. Alkaline proteases have found their largest use in domestic detergents. Proteases in the detergent industry account for approximately $25 \%$ of the total global enzyme sales (Demain and Adrio 2008). Other fields utilizing these 
enzymes include leather processing, the food industry, waste management, and silk degumming. Proteases can be harvested from plants, animals, or microorganisms, but the most efficient source is the microbes. Fungal strains have been successfully employed for this purpose. Fungi have many advantages over other microorganisms, such as their mycelia can be easily separated, and enzyme downstream processing is easier (de Souza et al. 2015). Many species of Aspergillus have been employed for this task (Devi et al. 2008). Researchers are competing for novel and more productive strains for protease production (Kumara and Takagi 1999). The current study aims to obtain a high yield of alkaline protease from Aspergillus flavus by estimating the most suitable conditions and checking the compatibility of the enzyme with commercial detergents.

\section{EXPERIMENTAL}

\section{Fermentative Organism}

Aspergillus flavus was used as fermentative organism for the production of alkaline protease. It was obtained from the Industrial and Environmental Biotechnology Laboratory, University Institute of Biochemistry and Biotechnology (UIBB), PMAS-Arid Agriculture University, Rawalpindi, Pakistan and was cultured on Potato Dextrose Agar media (PDA) having $\mathrm{pH}$ 5.5. All of the chemicals used were of analytical grade and purchased from Sigma Aldrich (St. Louis, Missouri, USA).

\section{Preparation of Fungal Inoculum}

The fungal inoculum was prepared for solid state fermentation (SSF) by transferring a loop full of $A$. flavus spores from the pure culture into $100 \mathrm{~mL}$ of liquid potato dextrose broth ( $\mathrm{pH} 5.5$ ). It was incubated in a shaking incubator to obtain $10^{7}$ to $10^{9}$ spores $/ \mathrm{mL}$ for 4 to 5 days.

\section{Solid State Fermentation}

For SSF, two substrates, i.e. wheat bran and rice bran, were screened for the production of alkaline protease for 8 days. Wheat bran showed higher activity with better fungal growth and was selected as the substrate for further study. It was collected from the local market and dried to zero moisture level and ground into a fine powder (mesh size 40 $\mathrm{mm}$ ). The required amount ( 2 to $10 \mathrm{~g}$ ) of the dried, ground substrate was placed in a 100$\mathrm{mL}$ flask. Distilled water was then added, which maintained the moisture level at 50\% $(\mathrm{w} / \mathrm{v})$ of the substrate. The flasks were cotton plugged and autoclaved at $121^{\circ} \mathrm{C}$ for $15 \mathrm{~min}$. The sterile solid substrate was inoculated with an inoculum of A. flavus, using a sterile pipette. The flasks were placed in the incubator at the required temperature for desired incubation time (according to the experimental design).

\section{Enzyme Extraction}

After the incubation, the flask containing the SSF culture was removed and $50 \mathrm{~mL}$ of distilled water was added. The culture was mixed and placed in the shaking incubator at $30{ }^{\circ} \mathrm{C}$ and $120 \mathrm{rpm}$ for $60 \mathrm{~min}$ for homogenization. The mixture was filtered through Whatman No. 1 filter paper. After filtration, the mixture was centrifuged at 10,000 rpm for $15 \mathrm{~min}$ at $4{ }^{\circ} \mathrm{C}$. The supernatant was stored as a crude enzyme at $4{ }^{\circ} \mathrm{C}$ and the pallet was discarded. 


\section{Alkaline Protease Assay}

Protease activity in the crude enzyme extract was determined using the protocol given by Chandrasekaran et al. (2015), using casein as the substrate. Tris-HCl buffer $(0.1$ $\mathrm{M}$ and $\mathrm{pH}$ 8.5; Sigma Aldrich, St. Louis, USA, was used to make $0.65 \%$ casein solution. A total of $5 \mathrm{~mL}$ of this solution was placed into all the vials, and they were kept at $37{ }^{\circ} \mathrm{C}$ for $5 \mathrm{~min}$ to $10 \mathrm{~min}$. Then, $1 \mathrm{~mL}$ of crude enzyme was collected from each of the enzyme samples and added into its respective reaction vial. No enzyme was placed in the blank vial. It was homogenized by gentle shaking and placed at $37{ }^{\circ} \mathrm{C}$ for $30 \mathrm{~min}$. To stop the reaction, $5 \mathrm{~mL}$ of chilled trichloroacetic acid (TCA), 10\%; solution was poured into all of the vials including the blank vial. The tubes were again kept for $30 \mathrm{~min}$ at room temperature. The solution from the vials was sieved through $0.45-\mu \mathrm{m}$ syringe filters. Then, $5 \mathrm{~mL}$ of $0.5 \mathrm{M}$ sodium carbonate $\left(\mathrm{Na}_{2} \mathrm{CO}_{3}\right)$ was added to $2 \mathrm{~mL}$ of the filtrate. The filtrate was taken in separate vials. Sodium carbonate solution was prepared by dissolving $26.5 \mathrm{~g}$ of the salt in $500 \mathrm{~mL}$ of the solution. For superior results, $1 \mathrm{~mL}$ of Folin-Ciocalteu (FC) phenol (2-fold diluted) reagent was added instantly after the sodium carbonate. The resulting solutions were placed in very dim light for $30 \mathrm{~min}$ at room temperature and a brilliant blue color was achieved. The absorbance of the blue color compound was measured at $660 \mathrm{~nm}$ against a reagent blank using tyrosine standard. One protease unit was defined as the amount of enzyme that releases $1 \mu \mathrm{g}$ of tyrosine per minute at $\mathrm{pH} 8.5$ at 37 ${ }^{\circ} \mathrm{C}$ (Lowry et al. 1951).

\section{Optimization of Physical Parameters for Maximum Enzyme Production}

Growth parameters, including incubation period, $\mathrm{pH}$, temperature, inoculum size, and substrate size, were optimized for the maximum production of alkaline protease through SSF using rice bran and wheat bran as substrates. Response surface methodology (RSM) was employed to design optimization experiments under central composite design (CCD). For this purpose, JMP 13.0 software (by SAS institute, Cary, NC, USA) was used, which designed 28 experiments with two central points. RSM is a statistical tool that was used to design experiments for studying the effect of various independent parameters on single dependent parameter. It reduced the number of treatments as well as time period for the research. The program analyzed the interaction between various parameters (independent) during their effect on the other parameters.

\section{Optimization of Carbon and Nitrogen Source for Maximum Enzyme Production}

Glucose, fructose, sucrose, ammonium sulfate, and urea were used as the carbon and nitrogen sources. The RSM was used under CCD, there were 28 experiments with two central points to optimize the 5 parameters simultaneously.

\section{Ammonium Sulphate Precipitation Method}

Proteins in the crude enzyme extract were purified by adding ammonium sulphate according to different saturation levels of the salt including $10 \%, 20 \%, 30 \%, 40 \%, 50 \%$, $60 \%, 70 \%, 80 \%$, and $85 \%$. The samples were left overnight at $4{ }^{\circ} \mathrm{C}$. Later the samples were centrifuged for $15 \mathrm{~min}$, at $4{ }^{\circ} \mathrm{C}$, and at $10,000 \mathrm{rpm}$. The pallets were dissolved in $1.5 \mathrm{~mL}$ of Tris- $\mathrm{HCl}$ buffer ( $\mathrm{pH} \mathrm{8.5)}$. Both the supernatant and the pallet were subjected to alkaline protease assay. 


\section{Gel Filtration Chromatography}

Gel filtration chromatography was performed for the enzyme purification. Sephadex G-100 resin (bead size 20 to $50 \mu \mathrm{m}$ ) was used for gel filtration chromatography, and it was packed in $3 \mathrm{~cm} \times 100 \mathrm{~cm}$ column. The gel was equilibrated with $0.05 \mathrm{M}$ tris- $\mathrm{HCl}$ buffer $(\mathrm{pH} 8)$ and eluted with the same buffer at a flow rate of $30 \mathrm{~mL} / \mathrm{h}$. Total 30 elusions $(1 \mathrm{~mL})$ were collected and first five were discarded and other 25 elusions were assayed for the alkaline protease activity.

\section{Characterization of Alkaline Protease}

The enzyme reaction was conducted at different values of $\mathrm{pH}$ (6.5 to 11.5) and temperature $\left(25\right.$ to $\left.50{ }^{\circ} \mathrm{C}\right)$ to calculate the optimum $\mathrm{pH}$ and temperature. Tris- $\mathrm{HCl}$ buffer was used to maintain $\mathrm{pH}$ from 6.5 to 8.5 and from 9.5 to 11.5 sodium bicarbonate buffer was used.

\section{Estimation of Kinetic Parameters}

The reaction of the enzyme was checked for multiple casein concentrations made in tris- $\mathrm{HCl}(0.1 \mathrm{M})$ buffer at optimum values of $\mathrm{pH}$ and temperature. The results obtained were used for the calculation of $K_{\mathrm{m}}(\mathrm{mg} / \mathrm{mL})$, and $V_{\max }$ (Units $/ \mathrm{mL} / \mathrm{min}$ ) calculated based on Michaelis-Menten model.

\section{Alkaline Protease Compatibility with Commercial Detergents}

Commercial detergent solutions $(7 \mathrm{mg} / \mathrm{mL})$ Surf Excel, Arial, Brite, and Bonus were prepared in distilled water. These solutions were boiled for $10 \mathrm{~min}$ to inactivate any already present proteases.

After cooling, the reaction mixture was made by adding $5 \mathrm{~mL}$ of $0.65 \%$ casein made in tris- $\mathrm{HCl}$ buffer $(0.1 \mathrm{M}, \mathrm{pH} 7.5)$ and $1 \mathrm{~mL}$ of detergent solution. After $10 \mathrm{~min}$ of incubation, $1 \mathrm{~mL}$ of enzyme solution was added to all the reaction mixtures. These were kept at $45{ }^{\circ} \mathrm{C}$ for $30 \mathrm{~min}$. After $30 \mathrm{~min}$, the reaction was stopped via the addition of $5 \mathrm{~mL}$ of $10 \%$ of TCA solution.

The mixture was left again at room temperature $\left(25^{\circ} \mathrm{C}\right)$ for $30 \mathrm{~min}$ and filtered through Whatman No. 1 filter paper. Then, $2 \mathrm{~mL}$ of the filtrate was transferred to a separate tube. Next, $5 \mathrm{~mL}$ of sodium carbonate $(0.5 \mathrm{M})$ was added, followed by $1 \mathrm{~mL}$ of $0.5 \mathrm{M} \mathrm{FC}$ reagent. The mixture was incubated at room temperature for $30 \mathrm{~min}$. and OD was noted at $660 \mathrm{~nm}$.

\section{Alkaline Protease Production on Wheat Bran and Rice Bran}

The production of alkaline protease was checked at the optimum level of all variables, i.e. $\mathrm{pH} 6$, temperature $30{ }^{\circ} \mathrm{C}$, time period $84 \mathrm{~h}$, inoculum size $3.5 \mathrm{~mL}$, substrate $6 \mathrm{~g}$, and $0.3 \%$ of each of the carbon and nitrogen sources. The experiment was conducted in triplicate with wheat bran and rice bran.

\section{Statistical Analysis}

A statistical analysis of the experimental data was conducted using JMP Response Surface Design and Surface Plot graphs. 


\section{RESULTS AND DISCUSSION}

\section{A. flavus Culture}

A. flavus was cultured on a PDA petri plate. After 2 days of growth, the immature colonies appeared velvety and white. The mature colonies after 5 days of incubation appeared dark green. For the preservation of fungus for the current study, its slants were prepared. There are less chances of contamination in slant culture due to less surface area.

\section{Solid State Fermentation}

As reviewed by Muthulakshmi et al. (2011), SSF was found to be an inexpensive and highly productive way of producing important enzymes including alkaline proteases. Agricultural byproducts can be used as cheap raw material for the synthesis of industrially important enzymes and chemicals. Rice bran was chosen as the substrate for A. flavus growth in SSF (Silva et al. 2005).

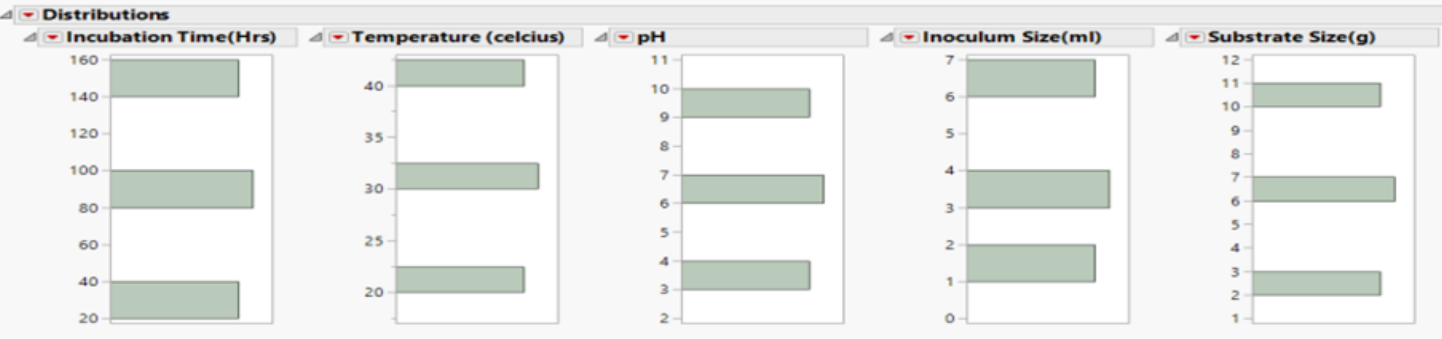

Fig. 1. Response surface design showing the distribution for physical factors

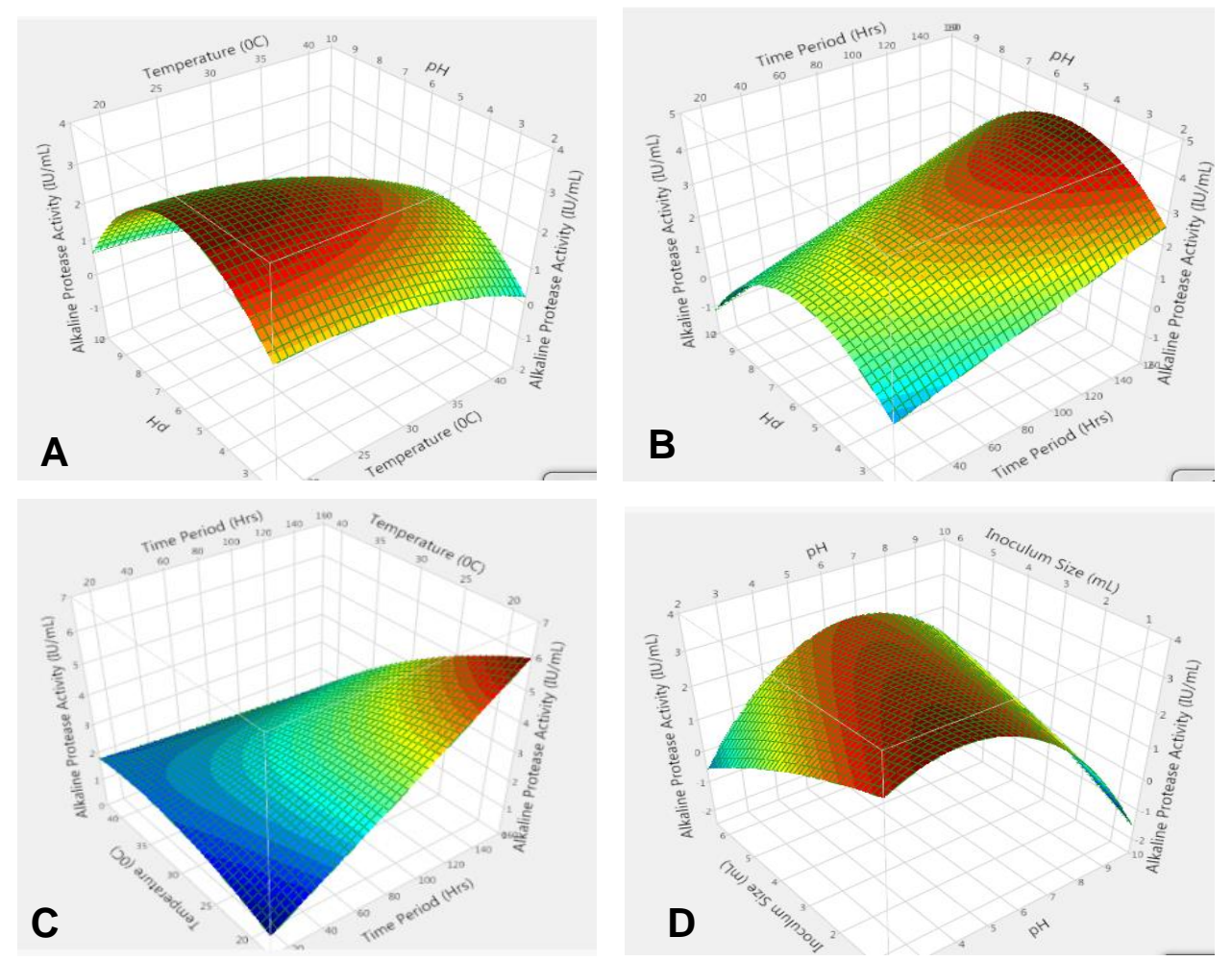

Fig. 2. 3D response surface graphs showing interaction between (a) Temperature \& $p H$ (b) Incubation time \& $\mathrm{pH}(\mathrm{c})$ incubation time \& temperature (d) $\mathrm{pH} \&$ inoculum size 


\section{Optimization of Parameters for A. flavus Growth and Enzyme Production}

Physical parameters - Optimization and interaction

A statistical analysis of the data by CCD and distribution analysis showed that the optimum $\mathrm{pH}$ and temperature for enzyme production were 6.0 and $30^{\circ} \mathrm{C}$, respectively. The highest activity was observed in the presence of $6 \mathrm{~g}$ substrate, $3.5 \mathrm{~mL}$ of fungal inoculum and after $84 \mathrm{~h}$ (Fig. 1).

Interaction among these parameters and the impact on enzyme production was studied. The results showed a positive interaction between various parameters (Fig. 2a-d). This positive interaction can be observed from the umbrella like graph and the peak of the graph indicates the highest activity at the values on the $\mathrm{x}$ - and $\mathrm{y}$-axis. The protease activity decreased on both sides of the peak value.

\section{Chemical parameters - Optimization and interaction}

The data obtained were processed by CCD and surface plots to obtain the optimum concentration of chemicals used and to study the interaction among the carbon nitrogen sources. The analysis of 3D response surface graphs showed that activity reached up to 6.5 $\mathrm{IU} / \mathrm{mL} / \mathrm{min}$, while the most suitable concentrations were $0.4 \%$ glucose, $0.2 \%$ fructose, $0.35 \%$ urea, and $0.2 \%$ ammonium sulfate (Fig. 3).
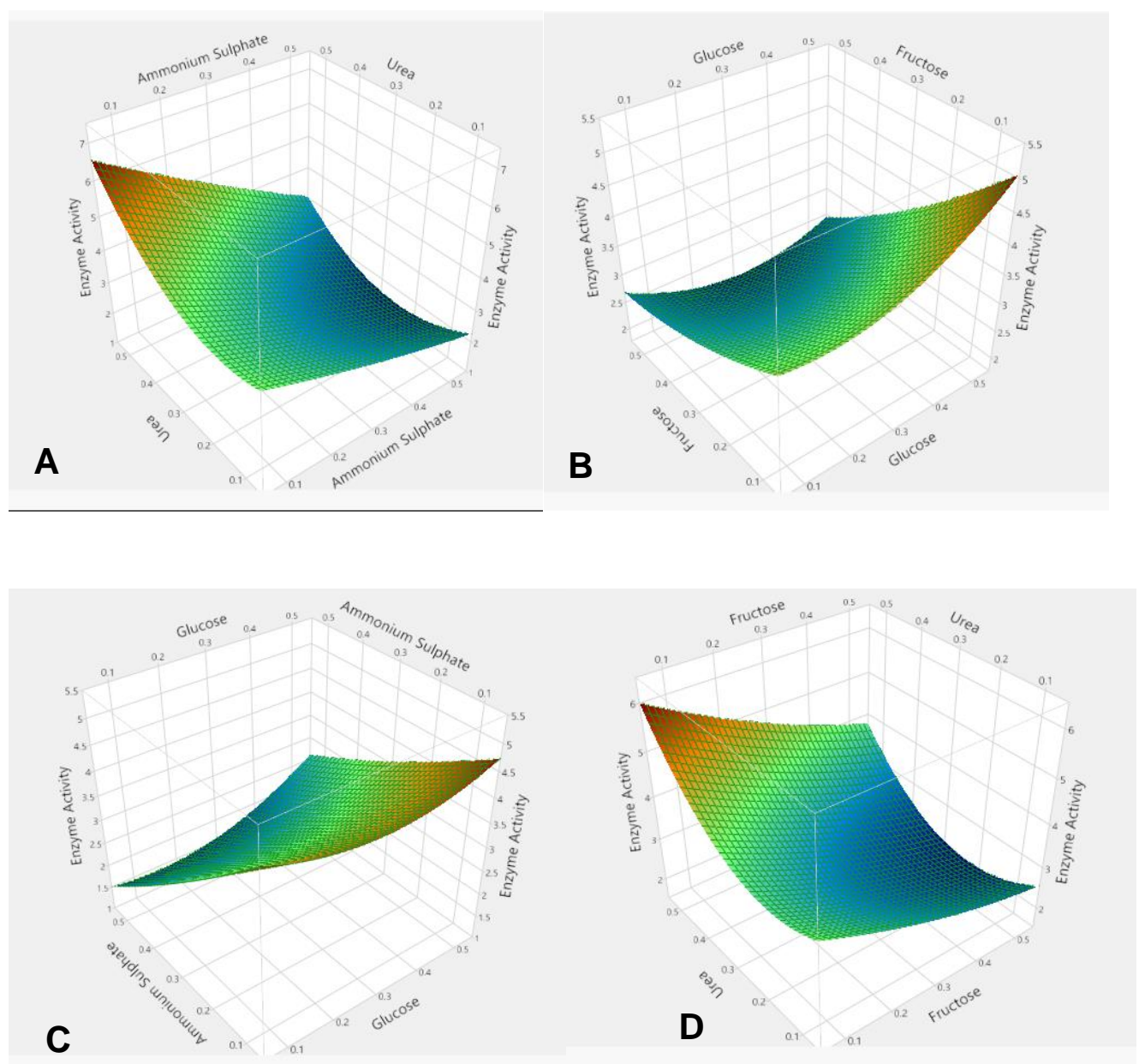

Fig. 3. 3D response surface graphs showing effect various carbon and nitrogen sources on alkaline protease through interaction between (a) glucose \& fructose, (b) ammonium sulfate \& urea, (c) glucose \& ammonium sulfate, and (d) fructose \& urea 


\section{Ammonium sulphate purification}

Partial purification of the enzyme was carried out at different percentages of ammonium sulphate ( $10 \%$ to $85 \%$ ) with $2 \mathrm{~mL}$ volume of crude enzyme for each $\%$ age. Maximum enzyme precipitation was observed at $80 \%$ saturation level. The pallet showed the higher alkaline protease activity compared to supernatant, indicating the precipitation of enzyme by salting out (Fig. 4).

\section{Gel filtration chromatography}

Sephadex G-100 (Sigma Aldrich, St. Louis, USA) was used to prepare the chromatographic column and calibrated with tris $-\mathrm{HCl}$ buffer $(\mathrm{pH} \mathrm{8.5)}$ and eluted with the same buffer. Thirty eluted samples, each of $1 \mathrm{~mL}$ volume, were taken. First, 5 elution samples were discarded, and the next were numbered as elusion samples 1 to 25 and were tested for their enzyme activity (IU/mL). Among the elusions, sample No. 6 gave the highest alkaline protease activity (Fig. 5).

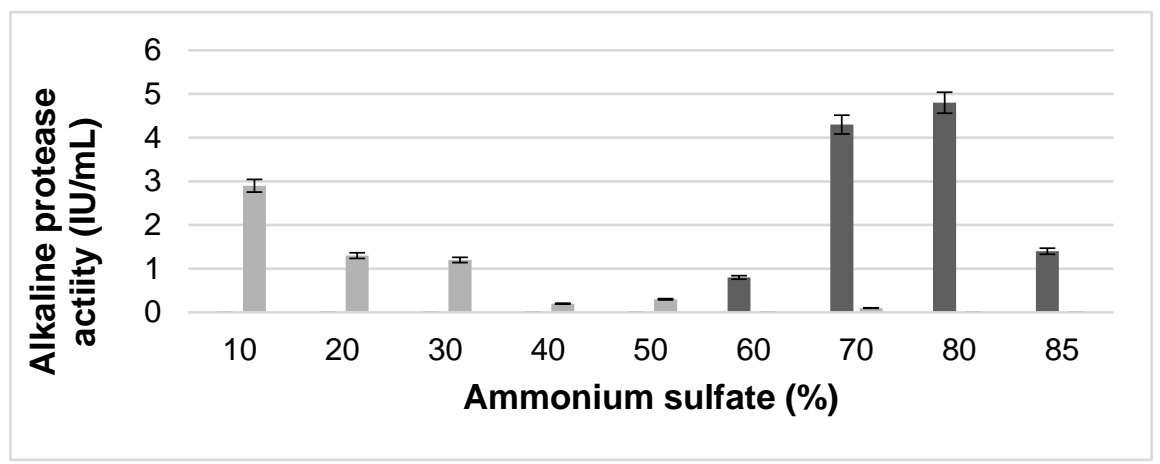

Fig. 4. Alkaline protease activity in supernatant (light) and pellet (dark), (SD represented by bars)

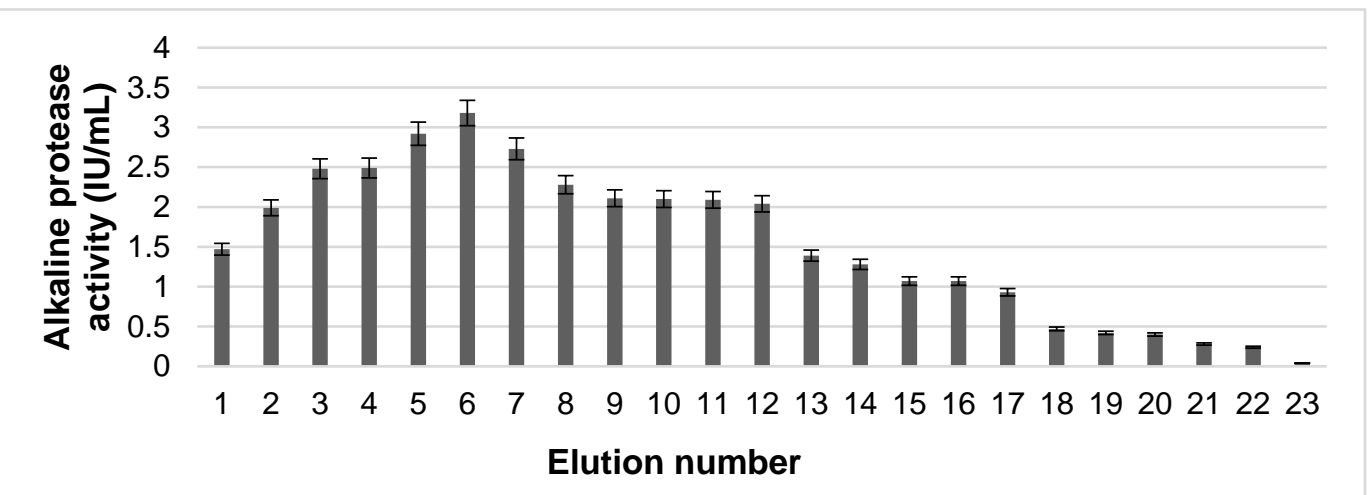

Fig. 5. Alkaline protease activity in eluted samples after gel filtration chromatography (SD represented by bars)

\section{Characterization of Alkaline Protease from A. flavus}

The alkaline protease was characterized for its optimum temperature by performing an assay at various temperature. The activity increased from $25{ }^{\circ} \mathrm{C}$ and reaches to maximum at $45{ }^{\circ} \mathrm{C}$, indicating its optimum temperature (Fig. 6). Similar results were obtained by Franco et al. (2017), where the highest value of enzyme activity was seen within the temperature range of 45 to $55^{\circ} \mathrm{C}$. Yadav et al. (2011) reported the maximum enzyme activity of protease from A. flavus at $40{ }^{\circ} \mathrm{C}$, whereas, a maximum activity was 
reported at $50{ }^{\circ} \mathrm{C}$ by experimenting with protease from A. flavus (Muthulakshmi et al. 2011).

Experiments for optimum $\mathrm{pH}$ showed the highest protease activity at $\mathrm{pH} 7.5$ (Fig. 7). The study by Yadav et al. (2011) showed that the protease extracted from A. flavus remains active in the $\mathrm{pH}$ range of 7 to 12, while according to Muthulakshmi et al. (2011) the protease from another $A$. flavus isolate showed maximum activity at $\mathrm{pH} 7$. The enzyme was active within the $\mathrm{pH}$ range of 7 to 8 as similarly reported by Chandrasekaran et al. (2015).

The effect of substrate, i.e. casein $(2 \mathrm{mg} / \mathrm{mL}$ to $20 \mathrm{mg} / \mathrm{mL})$ was used to calculate $K_{\mathrm{m}}$ and $V_{\max }$. The value of $V_{\max }$ was come out $3.9 \mathrm{U} / \mathrm{mL}$, while the value of $K_{\mathrm{m}}$ was 1.9 $\mathrm{mg} / \mathrm{mL}$ (Fig. 8).

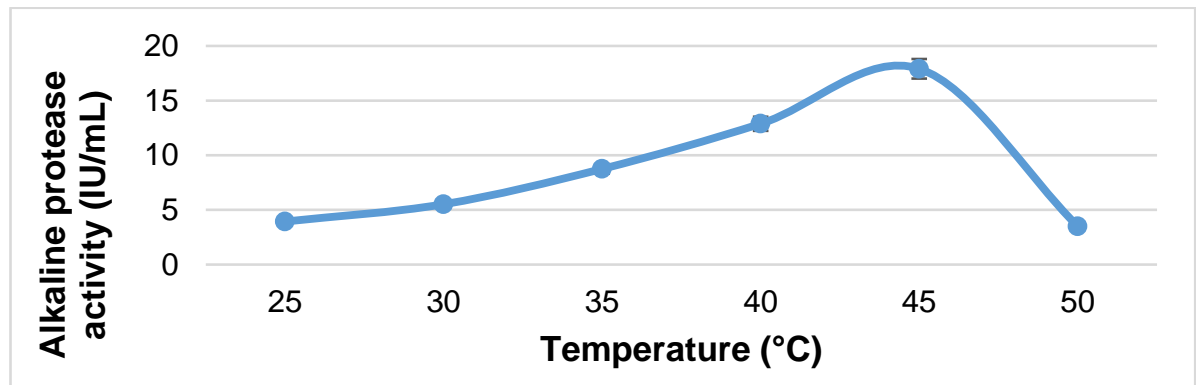

Fig. 6. Effect of temperature on alkaline protease activity (SD represented by bars)

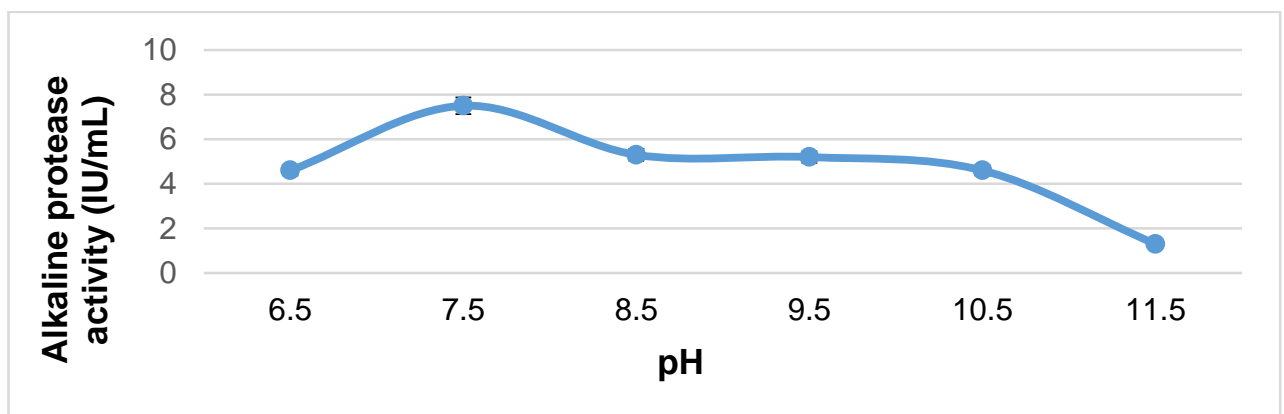

Fig. 7. Effect of $\mathrm{pH}$ on alkaline protease activity (SD represented by bars)

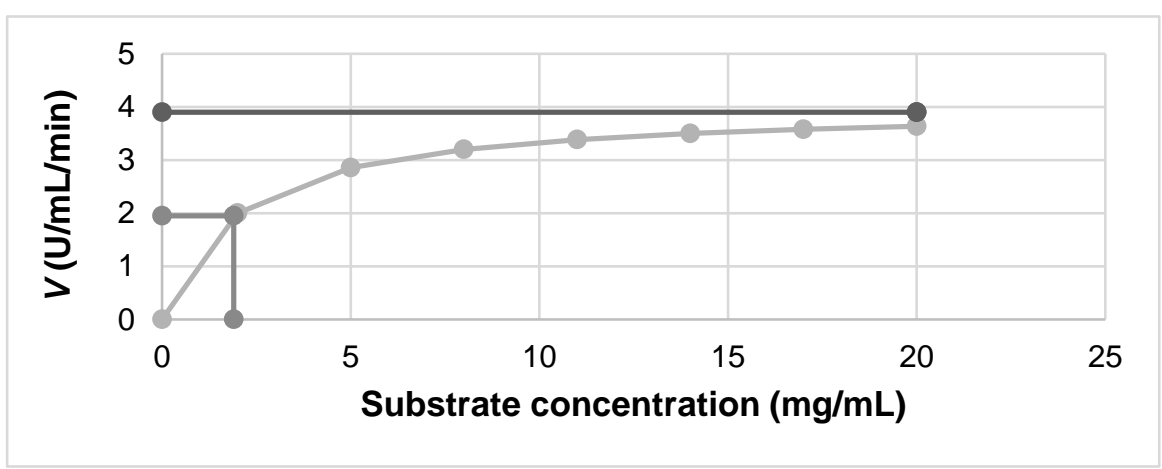

Fig. 8. Value of $K_{m}$ and $V_{\max }(\mathrm{U} / \mathrm{mL} / \mathrm{min})$

\section{Compatibility with Commercial Detergents}

The enzyme reaction was conducted in the presence of four different commercially available laundry detergents. The enzyme retained $80.8 \%$ and $79.5 \%$ of activity with Surf 
Excel, and Brite, respectively (Table 1). However, the activity was decreased to $70.5 \%$ with Ariel and 61.5\% in the presence of Bonus (Fig. 9).

The results showed that the enzyme worked efficiently in the presence of commercial laundry detergents. It retained much of its activity at a higher temperature and a basic $\mathrm{pH}$.

Further studies are recommended for testing the stain removing capability of the alkaline protease harvested from A. flavus in the presence of detergents. Moreover, future research may include modification of the enzyme through genetic manipulation to make it work in a higher basic environment.

Table 1. Protease Activity with Different Detergents

\begin{tabular}{|c|c|c|c|c|}
\hline Detergent & $\begin{array}{c}\text { OD at } 660 \\
\mathrm{~nm}\end{array}$ & Control OD & $\begin{array}{c}\text { Enzyme Activity } \\
(\mathrm{U} / \mathrm{mL})\end{array}$ & $\begin{array}{c}\text { Activity } \\
\text { Retained }(\%)\end{array}$ \\
\hline Control & 0.537 & 0.537 & 7.8 & 100 \\
\hline Brite & 0.431 & 0.537 & 6.2 & 79.5 \\
\hline Bonus & 0.340 & 0.537 & 4.8 & 61.5 \\
\hline Ariel & 0.385 & 0.537 & 5.5 & 70.5 \\
\hline Surf Excel & 0.435 & 0.537 & 6.3 & 80.8 \\
\hline
\end{tabular}

OD: Absorbance

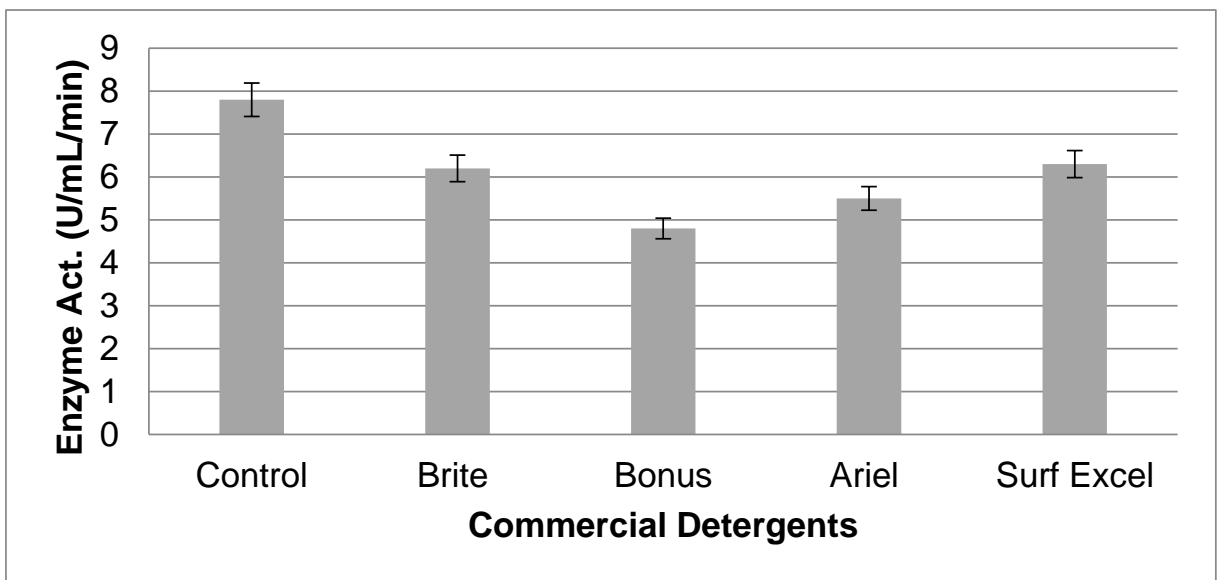

Fig. 9. Compatibility of alkaline protease form A. flavus with commercial detergents

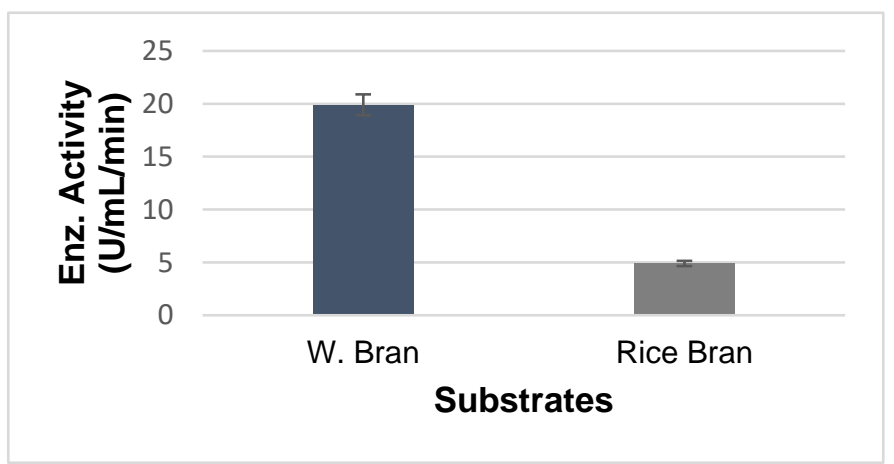

Fig. 10. Comparison of wheat bran and rice bran for alkaline protease production by A. flavus 


\section{Alkaline Protease Production at Optimized Conditions}

The enzyme production was checked at optimized conditions on both substrates for testing the efficacy of optimization process. There was enhanced production of alkaline protease when maintaining all conditions at optimum level. Like screening results there was more activity (19.90 IU.mL/min) when wheat bran was used as substrate compared to rice bran (4.90 IU/mL/min). Similar results were observed by Muthulakshmi et al. (2011), where wheat bran gave the best protease production among other solid substrates (Fig. 10).

\section{CONCLUSIONS}

The current study aimed to produce alkaline protease from A. flavus and to test its compatibility with commercially available detergents.

1. The physical and nutritional parameters for enzyme production were optimized, and the enzyme production was maximum when the fungus was grown at $\mathrm{pH} 6.0$ and a temperature of $30^{\circ} \mathrm{C}$, inoculum size $3.5 \mathrm{~mL}$, substrate $6 \mathrm{~g}$ for $84 \mathrm{~h}$.

2. The enzyme was precipitated between $60 \%$ to $85 \%$ ammonium sulphate, while the maximum precipitation was observed at $80 \%$.

3. The enzyme displayed maximum activity at $45{ }^{\circ} \mathrm{C}$ and retained most of its activity within the alkaline $\mathrm{pH}$ range of 7.5 to 10.5 .

4. The enzyme was found compatible with most of the commercially available detergents and retained $60 \%$ to $80 \%$ of its activity when assayed in the presence of the detergents.

5. Wheat bran was a better substrate for the enzyme production and it is recommended that wheat bran be used for the large-scale production of alkaline protease.

6. It was concluded that the alkaline protease produced from indigenously isolated $A$. flavus can be used for further studies for the development of bio-detergents.

\section{ACKNOWLEDGEMENTS}

Special thanks to the Institute of Biochemistry and Biotechnology, PMAS-Arid Agriculture University Rawalpindi for providing the facilities to carry out this research work.

\section{REFERENCES CITED}

Chandrasekaran, S., Kumaresan, S. S. P., and Manavalan, M. (2015). "Production and optimization of protease by filamentous fungus isolated from paddy soil in Thiruvarur District Tamil Nadu," Journal of Applied Biology \& Biotechnology 3(6), 066-069. DOI: $10.7324 / \mathrm{JABB} .2015 .3610$

Demain, A. L., and Adrio, J. L. (2008). "Contributions of microorganisms to industrial biology," Mol. Biotechnol. 38(1), 41-55. DOI: 10.1007/s12033-007-0035-z

De Souza, P. M., Bittencourt, M. L., de Freitas, C. C. M., de Almeida, R. P. C., Silveira, D., Fonseca, Y. M., Filho, E. X. F., Junior, A. P., and Magalhães, P. O. (2015). “A 
biotechnology perspective of fungal proteases," Braz. J. Microbiol. 46(2), 337-346. DOI: $10.1590 / \mathrm{S} 1517-838246220140359$

Devi, K. M., Banu, A. R., Gnanaprabhal, G. R., Pradeep, B. V., and Palaniswany, M. (2008). "Purification, characterization of alkaline protease enzyme from native isolate of Aspergillus niger and its compatibility with commercial detergents," Indian J. Sci. Technol. 1(7), 7-13. DOI: 10.17485/ijst/2008/v1i7/29599

Franco, D. G., Spalanzani, R. N., Lima, E. E., Marchetti, C. R., Silva, P. O., Masui, D. C., Giannesi, G. C., and Zanoelo, F. F. (2017). "Biochemical properties of a serine protease from Aspergillus flavus and application in dehairing," Biocatal. Biotransfor. 35(4), 249-259. DOI: 10.1080/10242422.2017.1322584

Kumara, C. G., and Takagi, H. (1999). "Microbial alkaline proteases: From a bioindustrial viewpoint," Biotechnol. Adv. 17(7), 561-594. DOI: 10.1016/S07349750(99)00027-0

Lowry, O. H., Rosebrough, N. J., Farr, A. L., and Randall, R. J. (1951). "Protein measurement with the folin phenol reagent," J. Biol. Chem. 193, 265-275.

Muthulakshmi, C., Gomathi, D., Kumar, D. G., Ravikumar, G., Kalaiselvi, M., and Uma, C. (2011). "Production, purification and characterization of protease by Aspergillus flavus under solid state fermentation," Jordan Journal of Biological Sciences 4(3), 137-148.

Raimi, O. G., Elemo, B. O., Fatai, A. A., Bankole, H. A., Kazeem, M. I., and Banjoko, A. O. (2011). "Isolation and partial characterization of a protease enzyme from Thaumatococcus daniellii waste," Afr. J. Biotechnol. 10(16), 3186-3190. DOI: 10.5897/AJB10.2065

Silva, D., Tokuioshi, K., Martin, E. S., Silva, R. D. and Gomes, E. (2005). "Production of pectinase by solid state fermentation with Penicillium viridicatum RFC3," Process Biochem. 40, 2885-2889.

Article submitted: February 5, 2018; Peer review completed: May 12, 2019; Revised version received and accepted: November 10, 2020; Published: November 16, 2020. DOI: 10.15376/biores.16.1.291-301 